\title{
The Development of a Method for the Identification of Problematic Students during the Initial Stage of Study
}

\author{
Norhana Arsad ${ }^{1,2}$, Noorfazila Kamal ${ }^{1,2}$, Afida Ayob ${ }^{1,2}$, Sarzliana Soaidin ${ }^{1,2}$ \& Hafizah Husain ${ }^{1,2}$ \\ ${ }^{1}$ Centre for Engineering Education Research, Faculty of Engineering \& Built Environment, Selangor, Malaysia \\ ${ }^{2}$ Department of Electrical, Electronic \& Systems Engineering, Faculty of Engineering \& Built Environment, \\ Selangor, Malaysia \\ Correspondence: Norhana Arsad, Department of Electrical, Electronic \& Systems Engineering, Faculty of \\ Engineering \& Built Environment, Universiti Kebangsaan Malaysia, 43600 UKM Bangi, Selangor, Malaysia. Tel: \\ 60-3-8921-8363. E-mail: norhana@eng.ukm.my
}

Received: October 5, 2012 Accepted: November 23, 2012 Online Published: November 30, 2012

doi:10.5539/ass.v8n16p209 URL: http://dx.doi.org/10.5539/ass.v8n16p209

\begin{abstract}
The decline in university students' performance has become an issue of great concern to university educators. Their academic excellence accomplished at school and pre-university levels do not warrant similar results when they are at the university. This study aims to prove that students' outstanding academic performance can actually be retained if they can be monitored as early as their first year of study at the university. Therefore, a method has been developed to identify students who are potentially problematic in their academic endeavours. The students were asked to sit for a basic test early in the first semester of their first year at university. The results of this test are then made as a yardstick to be compared with the results of their first semester examination. This study has found that the comparative results for both tests can be used to identify problematic students earlier on in their university life, and can be used as a basis for necessary actions by their academic facilitators.
\end{abstract}

Keywords: student identification, problematic students, academic performance, basic assessment

\section{Introducation}

\subsection{Higher Education in Malaysia and Predicting Student Performance}

Higher education in Malaysia has undergone a major reform since the 1970s. This starts with the New Economy Policy (NEP) introduced in 1971 which emphasises on education as an important agent for influencing socioeconomic positions (Faaland, Parkinson \& Saniman, 1990). Through provisions in the educational services, university became more open to various ethnics. By 1981, through the emergence of Tun Mahathir Mohamad as the Prime Minister, higher education policy shifted to emphasise on human resource development for growth more than inter-ethnic concerns (Hai, 2006). In the 1990s, five education-related acts were passed, all which affect both government funded and private higher education in some way or another.

These reforms in higher education in Malaysia have resulted in increased interests and motivation by high-school leavers to take up university study. To meet this expectation, the Malaysian government built more universities to provide the necessary study opportunities. As a result of this, there is an increasing diversity amongst the student population where students come from different social and cultural backgrounds, with different varying levels of education and life experiences. Consequently, it becomes a challenge for Malaysian universities to recognise this diversity and cater for this changing and varied population of students.

According to Power, Robertson and Baker (1987), "the stress should not only be on admitting a wider range of students, but also on giving them the support and help needed to ensure a reasonable chance of success". A number of work has been done to show the relationship between previous academic performance and university performance. The correlation between secondary school grades and CGPA at university is generally about 0.5 (Power et al., 1987). The predictive capability of the school grades to university performance does depend on many factors which include academic, psychosocial, cognitive and demographic elements.

\subsection{JKEES Student Performance}

Hafizah, Norbahiah, Norhana, Wan Mimi Diyana and Sarifah Nurhanum (2011) in Seminar Pendidikan 
Kejuruteraan \& Alam Bina 2011 (PeKA '11) has found that the achievements of students from the Department of Electrical, Electronic and Systems Engineering (JKEES) is on the decline and some students have been disqualified from their degree program as a result to such performance. Apart from that, the number of students who obtained the Cummulative Grade Points Average (CGPA) of less than 3.00 is on the rise. This has become an issue of grave concern not only to the department but to the Faculty of Engineering and Built Environment, Universiti Kebangsaan Malaysia (UKM). Looking at the problem superficially, this should not have happened since these students have undergone a very selective process before being accepted to university. Through the university selection scheme, only students with excellent results during the secondary school and pre-university stage were chosen. These students were also chosen based on their excellence in co-curricular activities.

It is thought that one of the contributing factors to this problem is the difference in education systems among secondary schools, pre-university and the universities. According to the National Education Philosophy, (or the 'Falsafah Pendidikan Negara'),

"Education in Malaysia an ongoing effort towards further developing the potential of individuals in a holistic and integrated manner, in order to produce individuals who are intellectually, spiritually, emotionally and physically balanced and harmoniously based on a firm belief in and devotion to God. Such an effort is designed to produce Malaysian citizens who are knowledgeable and competent, who possess high moral standards and who are responsible and capable of achieving a high level of personal well being to contribute to the betterment of the nation, family and society."

It becomes the responsibility of every individual, whether student or educators, to play the necessary role in order to fulfill the vision encompassed by this philosophy. The issue of poor academic performance among university students is a serious issue because of the high hopes put on university students by the community, that the students be individuals who are knowledgeable and are able to tackle current societal problems (Norhani, Noor Zainab, Hamidah \& Aminah, 2005).

Education is the main driving force for the development of the nation. The growth in higher education institution is important not only to produce a person who is knowledgeable in any particular field, but most importantly, to produce one who has excellent soft skills such as thinking skills, communication skills, team work, problem solving skills and other skills that are essential to meet up to the challenge of the $21^{\text {st }}$ century (Lee \& Tan, 2003). At school, the education system employed is more text-book oriented. However, the education system at university seems to be more tailored to students who have the skills to search for, understand and analyze information critically. In addition, over the last decade, the university has shifted to more outcome-based education system, where problem-based learning has been introduced.

Another factor that contributes to the declining performance of the students is the learning environment. Back when they were at school, students were supervised and controlled by the parents or caretakers and there were also extra classes available for those could afford them. Meanwhile, for students who stayed at the hostel, they had been allocated some time to study at some specific time. This is different with the university environment, where students have more freedom in determining the kinds of activities that they want to concentrate in or do.

Therefore, with a different environment and study methods, very few students were able to adapt themselves to the university environment. Meanwhile, the rest of them faced the problem of adjusting to the new environment so much so that their academic performances were affected.

Another most important skill that has to be acquired by UKM students is the learning skills (Mohamed Amin, 2010). It is also one of the contributing factors to academic performance. It has been found that students with poor study habits are more likely to withdraw from university or to have academic performance problems during the transition from secondary school to university (Pantages \& Creedon, 1975; Abbott-Chapman, Hughes \& Wyld, 1992).

In relation to this, we propose a method to identify problematic students so that they can be monitored from the early stage of their study by their mentors. With that, it is anticipated that the declining performance of the students are able to be mitigated. According to the Tenth Malaysian Plan (or 'Rancangan Malaysia Kesepuluh' RMK-10'), universities specifically the government-funded, must bear the responsibility on the achievement and performance of students as most of them are subsidised by public allocation. Therefore, it is necessary for JKEES to monitor JKEES students from time to time to ensure students academic success.

\section{Methodology}

A short test was distributed to 49 JKEES 1st Year students of the 2011/2012 session. This test seeks to evaluate 
students' performance during the early part of their study. This basic evaluative test contains 10 questions that are divided into three parts, which are Parts A, B and C. Part A ('BAHAGIAN A: KENDIRI') requires the students to reflect on themselves in English. This part tests the students' mastery of the English Language. Part B ('BAHAGIAN B: ASAS PENGETAHUAN') tests the students' basic understanding of electrical and electronic engineering, whilst Part C ('BAHAGIAN C: PENGETAHUAN UMUM') examines the students' general knowledge. The test questions can be referred to in Figure 1. All questions have to be answered in the form of an essay and must be completed in 60 minutes.

\begin{tabular}{|l}
\hline BAHAGIAN A: KENDIRI (Section A: Self-assessment) \\
\hline 1. Describe yourself. Why do you choose engineering? Please explain in English. \\
\hline BAHAGIAN B: ASAS PENGETAHUAN (Section B: Basic Knowledge) \\
\hline 2. J cos ax dx = \\
3. Apakah fungsi kapasitor dan perintang? Apakah kepentingan peranti ini dalam \\
bidang elektronik? (What is the function of a capacitor and resistor? What are \\
the importance of these dexces in the electronics feld?) \\
Apakah yang dimaksudkan dengan frekuensi (f)? Apakah kaitan antara frekuensi \\
(f) dan masa ( $t$ )? (What is meant by frequency (f)? What is the relationship \\
between frequency (f) and time ( $t$ )?) \\
Bezakan antara elektrik dan elektronik? (Differentiate between electrical and \\
electronics?) \\
Bezakan antara voltan dan arus? (Diferentiate between volts and current?) \\
Apakah yang dimaksudkan dengan kamiran dan pembezaan? Jel askan aplikasi \\
kedua-dua kaedah ini dalam sains dan teknologi? (What is meant by \\
differentiation and integration? Explain the application of both methods in \\
science and technology) \\
Apakah prinsip keabadian tenaga. (Explain the principle of conservation of \\
energy.) \\
BAHAGIAN C: PENGETAHUAN UMUM (Section C: General Knowledge) \\
9. What's the current technology in el ectric and electronics engineering? \\
10. Using your own words and perception, what do you think about nuclear crisis in \\
Japan? (BM/BI)
\end{tabular}

Figure 1. Test questions from the short test administered to the students

The test results have been made as the yardstick to determine the students who might have problems in their university study. To make the comparison easier to analyse, the students' marks have been mapped into the CGPA system that is applied in the university. The university CGPA system is a point based system in which an average of all of a student's grades for all semesters and courses completed up to a given academic term is calculated and the corresponding quality value is determined. A value of 4.0 indicates an $\mathrm{A}$, while a value of 1.0 indicates an E. Table 1 illustrates the mapping of the test marks to the university CGPA system.

The test results were then put in comparison with their first semester results and students were categorised into 4 groups based on these results. These groups were based on how far the students have adapted themselves to university life. Group A represents students who can really adapt themselves, Group B: students who are able to adapt themselves, Group C: students who have problems in adjusting themselves and Group D: students who are really problematic. Table 2 demonstrates the division of these 4 groups of students. This method of grouping assumes that the students who have adapted well with university life will not face any problems with their studies. Conversely, students who find it difficult to adapt to university life will face some or significant problems academically. This problem of social integration in university life does affect academic success since the emotional drag will affect their ability to focus on academic achievement (Melnick, Kaur \& Yu, 2011). 
Table 1 . The mapping of test marks to university CGPA

\begin{tabular}{cc}
\hline Test Marks $(0-10)$ & Test Marks (CGPA) \\
\hline 1 & 0.4 \\
2 & 0.8 \\
3 & 1.2 \\
4 & 1.6 \\
5 & 2.0 \\
6 & 2.4 \\
7 & 2.8 \\
8 & 3.2 \\
9 & 3.6 \\
10 & 4.0 \\
\hline
\end{tabular}

\begin{tabular}{cccl}
\hline \multicolumn{4}{l}{ Table 2. The method used to catagorise students' performance based on their CGPA } \\
\hline Group & $\begin{array}{c}\text { CGPA of Early } \\
\text { Assessment }\end{array}$ & $\begin{array}{c}\text { CGPA of 1st } \\
\text { Semester }\end{array}$ & Performance Level \\
\hline A & $>3.00$ & $>3.00$ & $\begin{array}{l}\text { Students who are really able to adapt themselves to the } \\
\text { learning environment }\end{array}$ \\
B & $<3.00$ & $>3.00$ & $\begin{array}{l}\text { Students who can adapt themselves } \\
\text { C }\end{array}$ \\
D & $>3.00$ & $<3.00$ & Students find it a problem to adapt themselves \\
& $<3.00$ & $<3.00$ & Students who are very problematic
\end{tabular}

With this segregation, the department is able to monitor the problematic students at an early stage so that their performance can be improved. The mentors for students in groups $\mathrm{C}$ and $\mathrm{D}$ has to play a bigger role in monitoring the students so better study performance can be guaranteed.

\section{Results and Discussion}

The comparison made between students' results at the pre-university and their results in the first semester is shown in Figure 2. 49 students were selected and each student is represented by the numbers 1 to 49 to ensure anonimity. It is found that out of 49 students, only $6(12 \%)$ have managed to retain their excellent academic position, whereas the rest have been shown to experience a decline in their performance. The students' academic achievement needs to be given due attention due to the fact that they are academically able students, as evidenced from their years in the pre-university stage, but have somehow faltered and experienced some potential problems, which causes them the inability to perform excellently in the first year examinations.

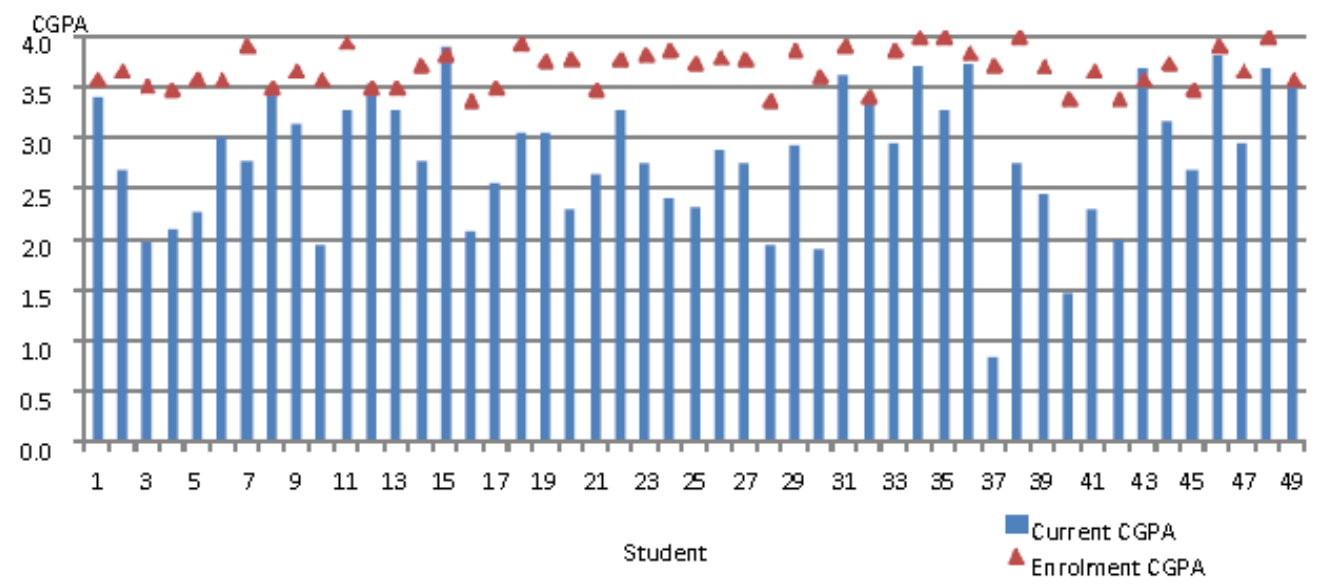

Figure 2. Enrolment CGPA and current CGPA of the first year JKEES students

To identify the problematic students, the results of the basic assessment were compared with the first semester results as demonstrated in Figure 3. From Figure 3, looking at the overall results, it can be seen that 14 (28.5\%) 
students obtained better first semester results that is lower than the entry test results.

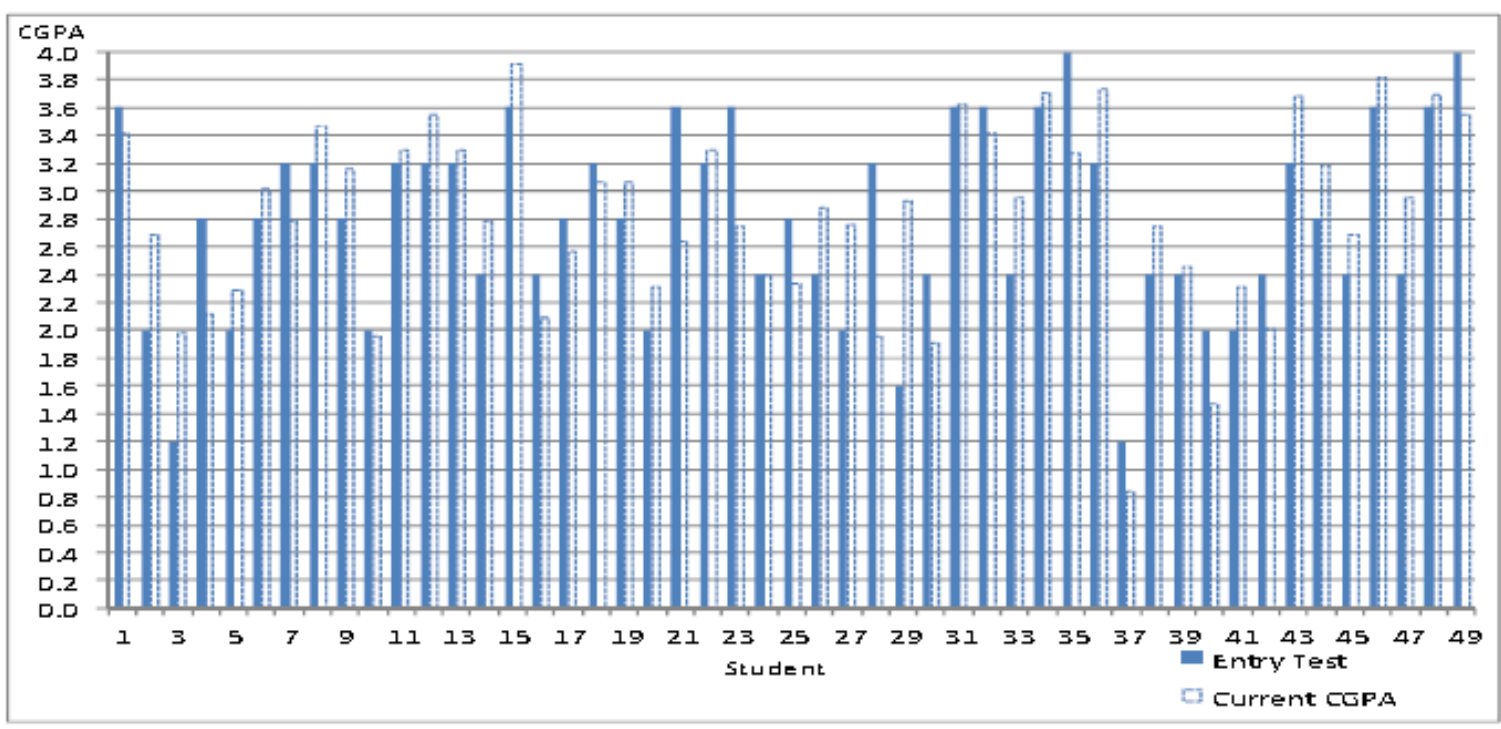

Figure 3. The graph of results (CGPA) of the basic assessment and $1^{\text {st }}$ semester tests of $1^{\text {st }}$ year JKEES students of the 2011/2012 session.

Based on this comparison, the students are then divided into 4 groups according to the categories stated in Table 2 above. Table 3 shows the numbers of students in each group. It is found that 17 students are in Group A where both the CGPAs for the basic assessment and the first semester test are more than 3.00. The students in this category are those categorised as students who can adapt very well to the university education system. There are 4 students in Group B. They obtained a CGPA of less than 3.00 in the basic assessment, but had a CGPA of more than 3.00 in the first semester. The students in this group can also be regarded as adaptable. Group $\mathrm{C}$ applies to students with the CGPA for the basic test of higher than 3.00 but their CGPA for the first semester declined to less than 3.00. There are 4 students in this group. Group D (of 24 students) consists of students with a CGPA of less than 3.00 for both basic and first semester tests. Students in Groups C and D, are those categorised as problematic students.

The total number of students in both Groups $\mathrm{C}$ and $\mathrm{D}$ is 28 . This amounts to $57 \%$ of the students who fall under the problematic group. These students will need more academic attention from their lecturers or facilitators.

Table 3. Distribution of students according to the grouping defined in Figure 2

\begin{tabular}{cc}
\hline Group & Number of Students \\
\hline A & 17 \\
B & 4 \\
C & 4 \\
D & 24 \\
\hline
\end{tabular}

According to Salleh and Zuria (2010), a university lecturer has to play the role of not only teaching but also guiding the students and facilitating them in resolving any issues related to their learning process. It is very important for university educators to realise this especially to the students who have been categorised to be in the problematic group.

\section{Conclusion}

The analysis obtained has managed to show the declining performance of the students at the university despite their excellent accomplishments at the pre-university stage. A basic assessment test at the early stage of the academic year has been introduced to look at performance of the students as soon as they enter university. The results were then compared with the results they obtained in the first semester to determine if they can adapt themselves to the university learning, or vice versa. By using this method, students who find it difficult to adapt to their learning environment can be identified the soonest possible. Therefore, by understanding their performance in first year university educators can develop effective learning programs to help students succeed. Further research must be conducted to find the relationship between non-academic factors such as college culture, 
roommate, religion and organization on campus with the performance of students. By exploring these factors in conjunction with the academic factors, campus administrators should be able to develop more effective education system which would benefit all university students.

\section{Acknowledgements}

This research is funded by the Universiti Kebangsaan Malaysia (UKM) under the Action Research Grant (PTS-2012-102) and OUP-2012-126. The authors would like to thank the committees of the Students Development Committee (JPPEL) of the Department of Electrical, Electronics and Systems Engineering, Faculty of Engineering and Built Environment, UKM, for their help in providing the necessary student data for this research and the Centre of Engineering Education in Universiti Kebangsaan Malaysia, Bangi for their support in this study.

\section{References}

Abbott-Chapman, J., Hughes, P., \& Wyld, C. (1992). Monitoring student progress: A framework for improving student performance and reducing attrition in higher education. Hobart: National Clearinghouse for Youth Studies.

Faaland, J., Parkinson, J. R., \& Saniman, R. (1990). Growth and Ethnic Inequality: Malaysia's New Economic Policy. Kuala Lumpur: Dewan Bahasa dan Pustaka.

Falsafah Pendidikan Kebangsaan, Matlamat dan Misi Kementerian Pendidikan Malaysia. Kementerian Pendidikan Malaysia. Kuala Lumpur.

Hafizah, H., Norbahiah, M., Norhana, A., Wan Mimi Diyana, W. Z., \& Sarifah Nurhanum, S. S. (2011). Analisis Kuantitatif Pencapaian Akademik Pelajar JKEES. Seminar Pendidikan Kejuruteraan dan Alam Bina (PeKA'11).

Hai, L. H. (2006). Malaysia: Distilling the lessons of forty years. In Leong, H. K. (Ed.), Re-thinking Administrative Reforms in Southeast Asia. Singapore: Marshall Cavendish Academic.

Lee, F. T., \& Tan, J. H. (2003). Project Management Skills Demand for Engineering Graduates in Malaysia. Buletin Bulanan IJM: Jurutera. Edisi June 2003. Selangor: Dimension Publishing Sdn. Bhd.

Melnick, K., \& Yu. (2011). Social Integration and Academic Outcomes: The Case of an International Public Policy and Management Program. Journal of Public Affairs Education, 17(4), 569-584.

Mohamed Amin Embi. (2010). Bimbingan Kemahiran Belajar. Pengalaman Pembelajaran Di UKM. Pengalaman Pembelajaran Di UKM 4:57-67.

Norhani Bakri, Noor Zainab Abd Razak, Hamidah Ab Rahman, \& Aminah Hj Ahmad Khalid. (2005). Punca Prestasi Pembelajaran Yang Lemah Di kalangan Pelajar Fakulti Pengurusan dan Pembangunan Sumber Manusia, UTM, Jurnal Teknologi. UTM, 43(E), 29-44.

Pantages, T. J., \& Creedon, C. F. (1975). Studies of college attrition: 1950-1975. Review of Educational Research, 48, 49-101.

Power, C., Robertson, F., \& Baker, M. (1987). Success in higher education. Canberra: Australian Government Publishing Service.

Rancangan Malaysia Kesepuluh (RMK-10). Membangun dan Mengekalkan Modal Insan Bertaraf Dunia. 5:194-251.

Salleh Amat, \& Zuria Mahmud. (2010). Penyeliaan Efektif. Pengalaman Pembelajaran Di UKM. 5:69-88. 